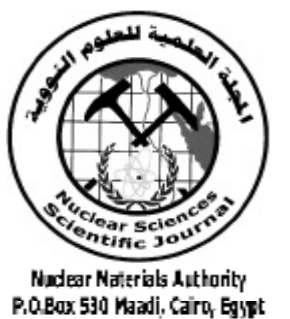

ISSN 2314-5609

Nuclear Sciences Scientific Journal

$7,135-149$

2018

http://www.ssnma.com

\title{
DISTRIBUTION OF RADIONUCLIDES IN URANIFEROUS TWO-MICA GRANITES AND THEIR ENVIRONMENTAL IMPACT AT EL SELA SHEAR ZONE, SOUTHERN EASTERN DESERT, EGYPT
}

\author{
ADEL H. EL-AFANDY; AHMED A. EL-KAMMAR ${ }^{1}$; AHMED E. ABDEL GAWAD and \\ TAHER N. RIZK \\ Nuclear Materials Authority, Kattamiya, Cairo , ${ }^{1}$ Dept. Geology, Fac. Sciences, Cairo Univ., Egypt
}

\begin{abstract}
The present study discusses the natural radioactivity in the uraniferous two-mica granites and their associated environmental impacts at El Sela area. Exposure rate (ER), dose rate (DR), radium equivalent activity $\left(\mathrm{Ra}_{\mathrm{eq}}\right)$, external hazard index $\left(\mathrm{H}_{\mathrm{ex}}\right)$, internal hazard index $\left(\mathrm{H}_{\mathrm{in}}\right)$ and radioactivity level index $(\mathrm{I} \gamma)$ were calculated. These rocks are dissected by microgranite and dolerite dikes which affected by different alteration process such as ferrugination, kaolinitization, illitization and flouritization which responsible about presence of some secondary uranium minerals. The radiometric investigations revealed that the uranium average contents up to 102.6 in microgranite dike, and reach to 194 in dolerite dike respectively. All the studied rocks had low values of eTh and K content. The exposure and dose rates exceeded the public permissible values in these dikes but they were within the safety range for workers and the public in the fresh two-mica granite. The expected environmental impacts may be low due to the limited occurrence of U-mineralization and corresponding areas for radiation exposure. Some precautions and recommendations were suggested to avoid any possible environmental impacts from areas and/or raw materials of high intensity of natural radiation sources.
\end{abstract}

\section{INTRODUCTION}

Generally, granites are considered as one of the most favorable host rocks for U-mineralization in the world especially the peraluminous two-mica granites (Cuney et al., 1984; Poty et al., 1986; Friedrich et al., 1989). In general, the granites are rich in incompatible elements ( $\mathrm{Rb}, \mathrm{Nb}, \mathrm{Sn}, \mathrm{Th}$, and U) (Rameshbabu, 1999; Pal et al., 2007). El Sela two-mica granites are considered as one of the most favorable areas for U-hosting mineralization in Egypt (Abdel Meguid et al. 2003; Ibrahim et al., 2007; El-Afandy et al. 2008; Ali, 2011; Abdel Gawad et al., 2014). It is located in the southern part of Egypt between latitudes $22^{\circ}$ $16^{\circ} 26^{\circ}-22^{\circ} 18^{\circ} 38^{\circ} \mathrm{N}$ and longitudes $36^{\circ} 13^{\circ}$ $33^{\circ}-36^{\circ} 16^{\circ} 26^{\circ}$ E (Fig. 1).

Natural radioactivity is associated mainly with primordial radionuclides including the elements belong to the ${ }^{238} \mathrm{U},{ }^{232} \mathrm{Th}$ and ${ }^{40} \mathrm{~K}$ series . The terrestrial background radiation is related to the type of rocks. The higher concentrations of uranium, thorium and potassium are associated with phosphate, calcrete and granite rocks (Nada, 2003; Nagdya, 2003; Abbady et al., 2005; Harb, et al., 2008; El Aassy, et al., 2012; Hamidalddin, 2012 and Walley El-Dine, 2012).

When a geological formation containing ${ }^{238} \mathrm{U}$ and ${ }^{232} \mathrm{Th}$ has not been disturbed (closed system) for more than a million years, the mem- 


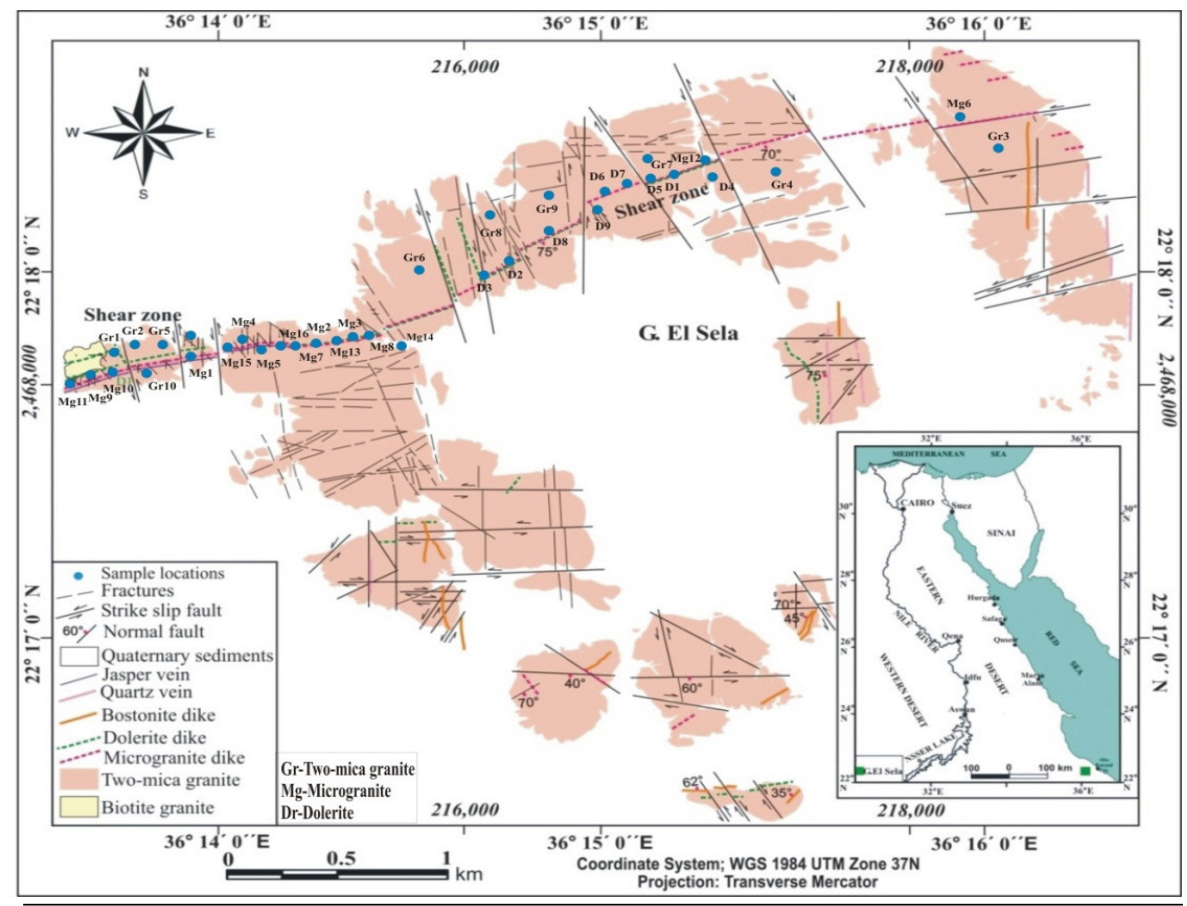

Fig. 1: Geological map of El Sela area, south Eastern Desert, Egypt (Modified after Ali, 2011)

bers of the individual decay series will have the same activity $\left(\mathrm{Bq} \mathrm{kg}^{-1}\right)$ which is known as secular equilibrium. However, when the geological formation is not closed to radionuclide migration, ${ }^{226} \mathrm{Ra}$ can migrate and be deposited somewhere outside the formation then secular equilibrium will not exist and the growth of ${ }^{226} \mathrm{Ra}$ by radioactive decay of its ancestors will not occur and ${ }^{226} \mathrm{Ra}$ is said to be unsupported. The geochemical mobility of natural radionuclides means that some environmental impacts and health effects may be caused if the exposure and dose rates of radiation exceed the permissible levels. Therefore, assessment of radiation doses from natural sources is of great importance where these sources are the largest contributor to the external dose of the world population (UNSCEAR, 2000).

The present work discusses the distribu- tion of the natural radionuclides and assess the radiological hazard resulting from the host two-mica granites, altered microgranite and dolerite dikes at the studied area using $\mathrm{NaI}(\mathrm{Tl})$ $\gamma$-ray spectrometers. The environmental background levels of natural radiation, human exposure and dose rates as well as possible environmental impacts of radiation were investigated.

\section{GEOLOGIC SETTING}

The detailed field observations detected the biotite granite and two-mica granite intrusions at G. El Sela area. These granites are dissected by microgranite, dolerite, bostonite dikes as well as three generations of quartz veins (Fig. 1). Quaternary sediments mostly comprise unconsolidated sands and gravels which are 
broadly categorized as undifferentiated wadi alluvium on the map sheet. They include outwash deposits, channel fill, terraced piedmont sands, gravels, and rock fragments of biotite granite, two-mica granite with different dikes and quartz vein.

\section{Biotite Granite}

Biotite granite is represented by small exposure at the northwestern part of the mapped area within the main shear zone (Fig. 1). It is pink to reddish pink in color, slightly leucocratic, massive, and exhibiting low to moderate relief with medium- to coarse-grained texture. Biotite granite masses imply cavernous, exfoliated and jointed surfaces caused by weathering processes. They are mainly composed of plagioclase, potash feldspars and biotite. Iron and manganese oxy-hydroxides represented by hematite, magnetite, goethite, and pyrolusite minerals fill rock joints and fractures as main and accessory constituents of this rock containing fine grained homogeneous enclaves of black color and oval to circular shape of metavolcanics. The biotite granite intruded the metavolcanis and intruded by two-mica granite with clear sharp intrusive contact.

\section{Two-Mica Granite}

Pink, reddish pink to pinkish grey twomica granite covers almost G. El Sela. It is represented by moderate to high relief masses forming the remnants of circular and/or domal-shaped granitic plutons (Fig.1). Furthermore, it is strongly weathered, cavernous, exfoliated, fractured and jointed along the ENE-WSW, N-S, NE-SW, NW-SE, and NNW-SSE trends. It is composed mainly of quartz, K-feldspar, plagioclase, biotite, and muscovite minerals with medium- to coarsegrained textures.

\section{Post Granitic Dikes and Veins}

Two-mica grranite are dissected by microgranite, dolerite and bostonite dikes along ENE-WSW, N-S, NE-SW, NW-SE, and
NNW-SSE directions. The microgranite dike is the oldest one. It is very fine grained, highly altered, whitish pink to pale pink in color and ranges from 3 to $15 \mathrm{~m}$ in thickness. It crosscuts the two-mica granite plutons along the ENEWSW main shear zone. It is dissected by the NW-SE dextral strike-slip faults, NNW-SSE, NNE- SSW, and N-S sinistral strike-slip faults (Figs. 1 and 2). This dike extends over more than $5 \mathrm{~km} \mathrm{SW}$ from the northern margin of El Sela plutons and enriched with visible U mineralizations. So, many open pits were made in order to evaluate their U contents (Fig. 3).

Dolerite dikes are fine- to medium-grained greyish green to dark grey in color. They range in width from 1.5 to $5 \mathrm{~m}$ thick. They yield onion like boulders and essentially composed mainly of plagioclase with mafic olivine and pyroxene. They have ENE-WSW, NNW-SSE, NE-SW, and N-S major trends (Fig. 1). ENE-WSW and NNW-SSE dikes are enriched with visible $\mathrm{U}$ mineralization and pyrite. The first trend in which dolerite strikes ENE-WSW and dipping $70^{\circ}$ to $80^{\circ} \mathrm{S}$ is adjacent to microgranite in some parts of the mapped area. The second mineralized trend of dolerite strikes NNW-SSE and dipping $56^{\circ} \mathrm{W}$. The microgranite and dolerite dikes are corre-

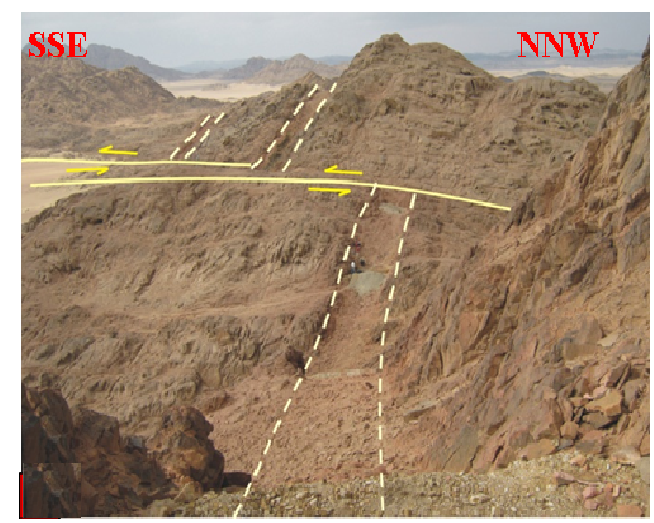

Fig.2: Photomicrographs showing microgranite dike invades two-mica granite crosscut by NNWSSE sinistral strike-slip fault at El Sela area 


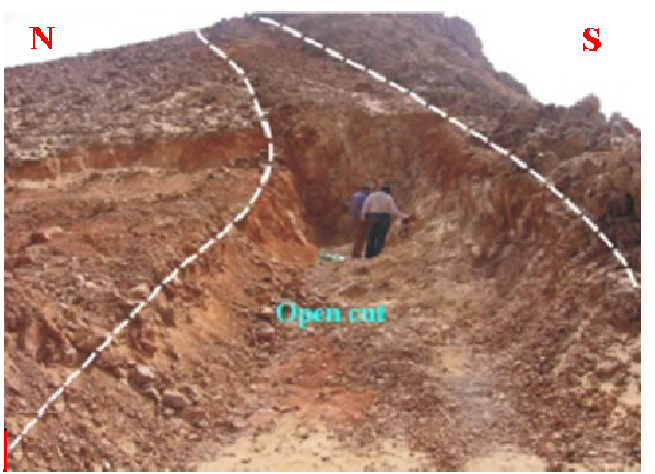

Fig.3: Photomicrographs showing open cut in microgranite dike at El Sela area

sponded to major radiometric anomalies in the spectrometric maps than the ambient two mica granite (Gaafar 2005, Abu Donia 2006).

Bostonite dikes display different colors ranging from pale brown, buff to reddish brown according to the intensity of iron oxy-hydroxides staining. They are very fine grained, massive, fractured and jointed, displaying compact appearance. They are of 0.5 to $2 \mathrm{~m}$ in thickness and occur along the $\mathrm{N}-\mathrm{S}$ and $\mathrm{NE}-\mathrm{SW}$ trends. They are mainly composed of K-feldspar, plagioclase, little quartz, and iron oxides. They have the lowest $U$ content in the studied area. The main shear zone is characterized by the existence of three generations of white quartz and jasperoid black veins invade the two-mica granite and existing along ENE-WSW major trend (Fig. 1).

The quartz veins bound the microgranite and dolerite dikes and dissect them in concordant with successive fractures corresponding to repeated rejuvenations of the ENE-WSW major trend. The first phase is white, highly brecciated barren quartz ( 1 to $4 \mathrm{~m}$ thickness); the second is highly radioactive beige to grey jasper which sometimes changes to a red color along the fractures by ferrugination (20 to 80 $\mathrm{cm}$ thickness). These veins are, strongly jointed, fragmented, brecciated, and cemented by the third black silica phase rich in U mineralization or by white quartz in other places (Fig.
4). El Sela granitic pluton are affected by sets of faults trending ENE-WSW, NNW-SSE, NNE-SSW, NW-SE, and N-S showing dextral and sinistral sense of movement (Fig.1). The ENE-WSW and NNW-SSE are considered the important tectonic trends which control the multi-injections and many alteration features in the study area. During reactivation, a simple shear parallel to the inherited ductile fabrics was responsible for the development of mineralized structures along the ENE-WSW and NNW-SSE trends. They can be considered as paleochannel trends for deep-seated structures and can act as a good trap for uranium and/or other mineral resources (Ali 2011).

Unmappable pegmatite pockets were found as irregular bodies within biotite granite and two-mica granite. They are very coarse grained, buff to reddish pink in color, highly sheared (Fig. 5) and composed of K-feldspar, quartz, plagioclases, biotite with muscovite. They show higher content of total radioactivity than two-mica granite.

\section{Alterations and Mineralizations}

Due to the repeated magmatic activities, reactivated tectonic trends especially ENEWSW and NNW-SSE and the associated fluids, many alteration halos are observed. Silicification, ferrugination, kaolinization, illitization and fluoritization (with violet to black

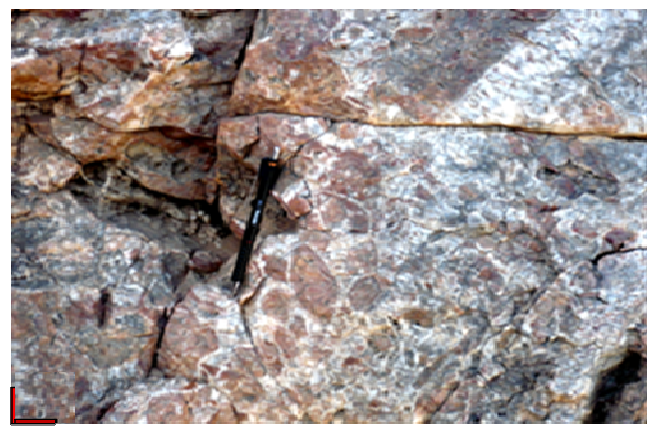

Fig.4: : Close up view of brecciated jasperoid vein cemented by white quartz in the main shear zone at El Sela area 


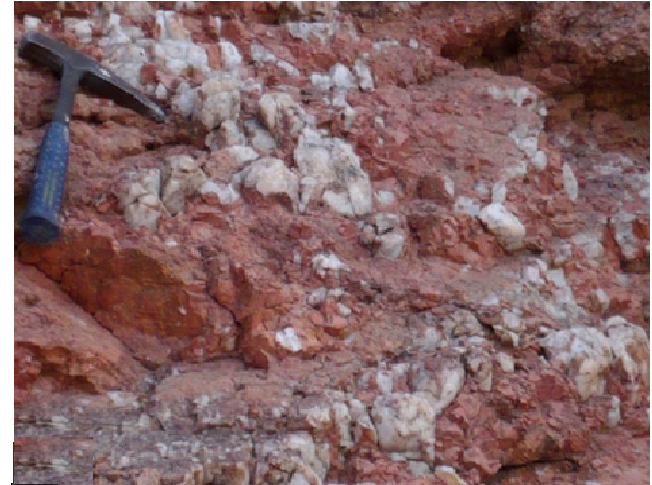

Fig.5: Photomicrographs showing sheared pegmatite pockets cut two-mica granite in the main shear zone

fluorite) were recorded (Figs. 6,7\&8). The ENE-WSW shear zone of the

Northwestern part of G. El Sela is occupied by massive, amorphous silica of light grey, red, to black colors of jasperoid vein and highly silicified microgranite dike. Silicified microgranite along the main shear zone has a noticeable amount of liberated secondary silica that occurs as fine crystals associated with the large primary quartz crystals enriched by uranophane.

Kaolinization indicates that the rocks were affected by acidic solution with low temperature varying from 200 to $250{ }^{\circ} \mathrm{C}$ (Helgeston 1974). Kaolinitization process causes an increase in alumina at the expense of the other major oxides. In shear zone, kaolinization affects microgranite dike which characterized by the formation of kaolinite associating with veinlet filled with uranophane (Fig. 9). Ferrugination causes increase in total $\mathrm{Fe}_{2} \mathrm{O}_{3}$ content at the expense of other oxides. The strong alkaline solution may precipitate $\mathrm{Fe}^{+3}$ and $\mathrm{U}^{+6}$ within the microfractures in the form of iron oxy-hydroxides rich in uranium (Cuney, et al., 1984). Microgranite samples stained by Fe oxides adsorb $U$ element at the main shear zone of G. El Sela area (Figs. 7\&9). Ferrugination is represented mainly by hematite and goethite minerals.

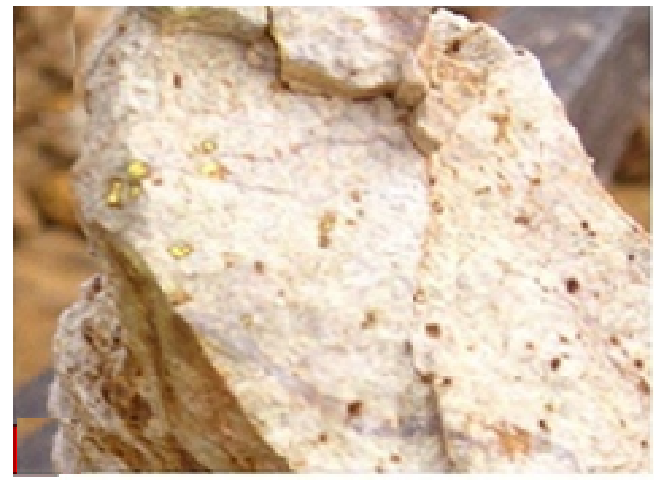

Fig.6: Visible uranophane fill the vugs of dissolved pyrite in silicified and albitized samples (Alteration process)

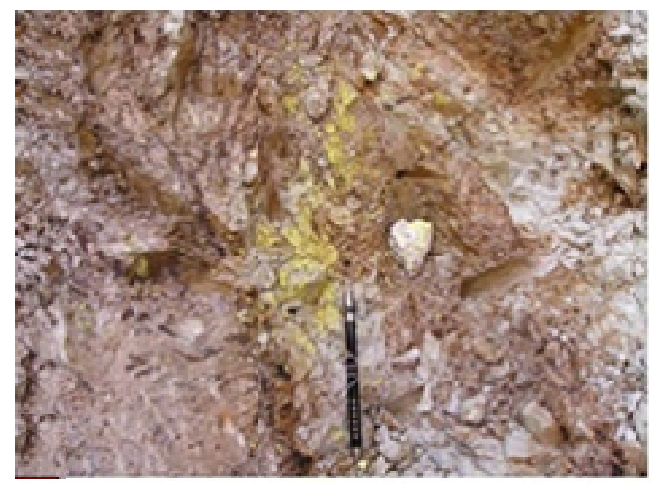

Fig.7: Ferrugination associating visible uranophane

Illite and fluorite alterations are observed mainly in arc-shaped granite (3.6 km in length). Microgranite altered samples display clear illitization and the original textures nearly disappeared. The K-feldspar, plagioclase and biotite are strongly altered to illite (K alteration of biotite produce illite, followed by fluoritization where the fluorite was emplaced through the fractures in this zone). The solution caused alteration of the $\mathrm{K}$-feldspars, plagioclase and biotite to illite according to Hemley and Jones (1964) and Pirajono (1992): 


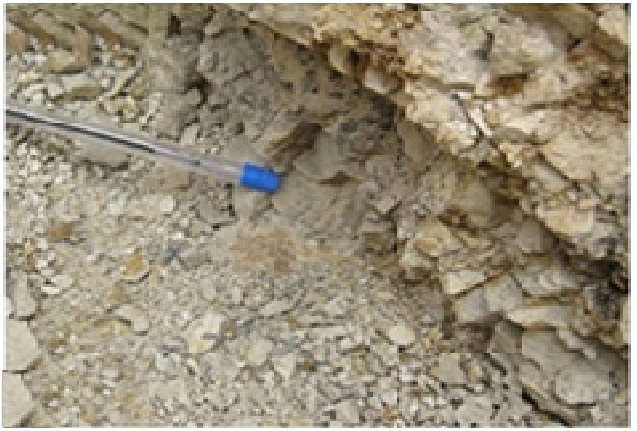

Fig.8: Clay rich matrix (illitization) associating violet fluorite

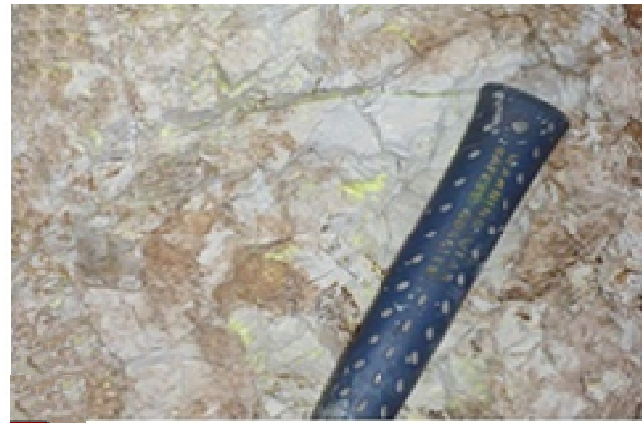

Fig.9: Microfructures in illite zone filled with uranophane

$3\left(\mathrm{~K} \mathrm{Al} \mathrm{Si}_{3} \mathrm{O}_{8}\right)+\left(2 \mathrm{H}^{+}\right) \rightarrow \mathrm{K} \mathrm{Al}_{2}\left(\mathrm{Si}_{3} \mathrm{Al} \mathrm{O}_{10}\right)\left(\mathrm{OH}_{2}+2 \mathrm{~K}^{+}+6\left(\mathrm{SiO}_{2}\right)\right.$

K-feldspar acid solution illite quartz
$6\left(\mathrm{Na} \mathrm{Al} \mathrm{Si}_{3} \mathrm{O}_{8}\right)+2 \mathrm{~K}^{+}+4 \mathrm{H}^{+} \rightarrow 2\left[\mathrm{~K} \mathrm{Al}_{2}\left(\mathrm{Si}_{3} \mathrm{Al} \mathrm{O}_{10}\right)\left(\mathrm{OH}_{2}\right)_{2}\right]+12\left(\mathrm{SiO}_{2}\right)+6 \mathrm{Na}^{+}$
Na-Plagioclase $\quad$ illite $\quad$ quartz
$\left.3\left[\mathrm{Ca} \mathrm{Al}_{2} \mathrm{Si}_{2} \mathrm{O}_{8}\right)\right]+2 \mathrm{~K}^{+}+4 \mathrm{H}^{+} \rightarrow 2\left[\mathrm{~K} \mathrm{Al}_{2}\left(\mathrm{Si}_{3} \mathrm{Al} \mathrm{O}_{10}\right)\left(\mathrm{OH}_{2}\right)_{3}\right]+3 \mathrm{Ca}^{++}+4 \mathrm{Al}^{3}+3 \mathrm{Si}^{4+}$
Ca-plagioclase

The excess of released quartz can migrate as colloidal silica to precipitate later in the tension fractures as jasperoid veins at upper structural levels under low temperature condition or caused silicification for the granite near the illite zone (Fig. 10). Also the released $\mathrm{Na}$ from sodic-plagioclase during the illitization resulted in albitization around the illite zone. The free $\mathrm{Al}^{3+}$ increase the alumina in the illite.

$3\left[\mathrm{~K}(\mathrm{Mg}, \mathrm{Fe})_{3}\left(\mathrm{AlSi}_{3} \mathrm{O}_{10}\right)(\mathrm{OH}, \mathrm{F})_{2}\right]+2 \mathrm{H}^{+} \rightarrow \mathrm{KAl}_{2}\left(\mathrm{Si}_{3} \mathrm{AlO}_{10}\right)(\mathrm{OH})_{2}+2 \mathrm{~K}(\mathrm{OH})+9 \mathrm{Mg}+6 \mathrm{SiO}_{2}$ $+2 \mathrm{H}_{2} \mathrm{O}+80 \uparrow+6$ Biotite $\quad$ illite quartz

The released $\mathrm{Ca}$ and $\mathrm{F}$ during illitization of the calcic plagioclase and biotite may compound together forming calcium fluoride $\mathrm{CaF}_{2}$ which is observed within the illite zone. This kind of alteration by acid solution is responsible for leaching of uranium from the hosting two-mica granite enriched by easily soluble U-minerals and its redeposition in microgranite dike these criterias are analogue to these of G. El Missikat area (Abdel Meguid et al., 2003). These microgranite dike also extremely enriched in extensive pyrite and magnetite in the vugs where the pyrite cubes are dissolved, visible secondary uranium minerals especially uranophane are seen in the highly silicified and albitized samples while fluorite associates the illite zone (Figs. 6-8).

\section{ANALYTICAL TECHNIQUES}

Thirty six representative samples from the two-mica granite, altered microgranite and dolerite dikes, were collected (Fig. 1). These

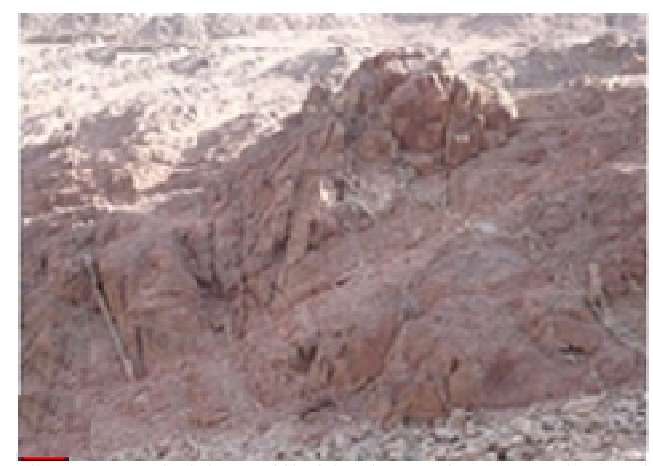

Fig.10: Highly silicified and ferruginated muscovite-biotite granite. 
samples were measured in the laboratory for their U, Th, Ra and $\mathrm{K}$ contents using a high efficiency multichannel analyzer of $\gamma$-ray spectrometer $\mathrm{NaI}(\mathrm{Tl})$. The radiometric measurement for these radionuclides was carried out through four energy regions of interests (ROIs). Since uranium and thorium are not $\gamma$-emitters, they were measured indirectly through the $\gamma$-ray photons emitted from their daughters, Th-234 (81-108 keV) for U-238, $\mathrm{Pb}-212$ (221-273 keV) for Th-232 and radium was measured from the gamma-ray photon emitted by $\mathrm{Pb}-214$ (327-390 keV) whereas potassium was measured directly from the gamma-ray photon emitted by K-40 (1319$1471 \mathrm{keV})$. Consequently, they are expressed as equivalent uranium (eU), equivalent thorium (eTh) and equivalent Radium (eRa). The chosen energy regions for $\mathrm{U}, \mathrm{Th}, \mathrm{Ra}$ and $\mathrm{K}$ were determined from the indicated energy lines of the spectra generated by means of laboratory uranium, thorium, radium and potassium reference standard samples provided by the IAEA (Matolin, 1991).

The samples were prepared for measurement according to procedures described by (Matolin, 1991; Hamby and Tynybekov, 2000; Al-Jundi, 2002).

Values of eU, eTh and eRa, in ppm, as well as $\mathrm{K}$, in $\%$, were converted to activity concentration, $\mathrm{Bq} \mathrm{kg}{ }^{-1}$, using the conversion factors given by Polish Central Laboratory for Radiological Protection (Malczewski et al., 2004). These data were used for calculation of some radiological parameters to estimate the environmental impacts of the radionuclides as would be shown later.

\section{RADIATION HAZARD INDICES}

Direct external exposure to radiation, inhalation, and ingestion of radioments are the main and pathways by which some environmental impacts may be caused. This depends on several factors including type and energy of radiation, total doses, size of irradiation section, the radio-sensitivity of the individual and age (Rumyantsev, 1967).

Exposure is a measure of ionization caused by X-ray or gamma radiation. The exposure and dose rates related to the measured radionuclides in the studied sediments are discussed through determination of their values and in terms of radium equivalent activity. The exposure rate $(\mathrm{mR} / \mathrm{h})$ is determined using the following equation (Grasety et al., 1984):

Exposure rate $(\mathrm{ER})=0.653 \mathrm{eU}(\mathrm{ppm})+0.287 \mathrm{eTh}(\mathrm{ppm})+1.505 \mathrm{~K}(\%)$

where $0.653,0.287$ and 1.505 are the conversion factors for $\mathrm{U}, \mathrm{Th}$ and $\mathrm{K}$, respectively. The radiation doses received by people are frequently measured in REM (roentgen equivalent man). For gamma radiation, the conversion from exposure to dose rate is given as 1 $\mathrm{mR} / \mathrm{h}=8.33 \mathrm{mrm} / \mathrm{y}$. Then, the dose rate(D), in $\mathrm{mrm} / \mathrm{y}$, is calculated as $\mathrm{D}=\mathrm{E} * 8.33$.

The most widely used radiation hazard index $\left(\mathrm{Ra}_{\mathrm{eq}}\right)$ is called the radium equivalent activity. ( $\mathrm{Ra}^{\text {) }}$ ) is a weighted sum of activities of the ${ }^{226} \mathrm{Ra},{ }^{232} \mathrm{Th}$ and ${ }^{40} \mathrm{~K}$ radionuclides based on the assumption that $370 \mathrm{~Bq} \mathrm{~kg}^{-1}$ of ${ }^{226} \mathrm{Ra}, 259$ $\mathrm{Bq} \mathrm{kg}^{-1}$ of ${ }^{232} \mathrm{Th}$ and $4810 \mathrm{~Bq} \mathrm{~kg}^{-1}$ of ${ }^{40} \mathrm{~K}$ produce the same gamma ray dose rate (Krisiuk et al., 1971). The exposure to radiation (Beretka and Mathew, 1985; Tufail et al., 1992) can be defined in terms of the radium equivalent activity $\left(\mathrm{Ra}_{\mathrm{eq}}\right)$, which can be expressed by the following equation:

\section{$\mathrm{Ra}_{\mathrm{eq}}=\mathrm{A}_{\mathrm{Ra}}+10 / 7 \mathrm{~A}_{\mathrm{Th}}+10 / 130 \mathrm{~A}_{\mathrm{K}} \leq 370$}

where $A_{R a}, A_{T h}$ and $A_{K}$ are the specific activities of ${ }^{226} \mathrm{Ra},{ }^{232} \mathrm{Th}$ and ${ }^{40} \mathrm{~K}$, respectively, in $\mathrm{Bq} \mathrm{kg}^{-1}$. The permissible value of $\mathrm{Ra}_{\mathrm{eq}}$ is $\leq$ $370 \mathrm{~Bq} \mathrm{~kg}^{-1}$ (Tufail et al., 1992). Conversion factors to transform specific activities $A_{R a}, A_{T h}$ and $A_{K}$ of $R a$, Th and $K$, respectively, were used to calculate the radium equivalent activity for the present study .

To limit the annual external $\gamma$-ray dose (Saito and Jacob 1995; Saito, et al., 1998; UNSCEAR, 2000) to 1.5 Gy for the samples 
under investigation, the external hazard index $\left(H_{e x}\right)$ is given by the following equation:

$$
H_{e x}=A_{R a} / 370+A_{T h} / 259+A_{K} / 4810 \leq 1
$$

The internal exposure to ${ }^{222} \mathrm{Rn}$ and its radioactive progeny is controlled by the internal hazard index $\left(H_{i n}\right)$, which is given by Nada (Nada 2003):

$$
H_{\text {in }}=A_{R_{2}} / 185+A_{T h} / 259+A_{K} / 4810 \leq 1
$$

The radioactivity level index $\left(\mathrm{I}_{\gamma}\right)$ is used to estimate the level of radiation risk, especially $\gamma$-ray associated with natural radionuclides in specific materials. It is defined as (NEAOECD, 1979).

$$
\mathrm{I}_{y}=\mathrm{A}_{\mathrm{R}_{\mathrm{a}}} / 150+\mathrm{A}_{\mathrm{Th}} / 100+\mathrm{A}_{\mathrm{K}} / 1500 \leq 1
$$

where $\mathrm{I}_{\gamma}$ is the radioactivity level index and $\mathrm{A}_{\mathrm{Ra}}, \mathrm{A}_{\mathrm{Th}}^{\gamma}$ and $\mathrm{A}_{\mathrm{K}}$ are the specific activities of $\mathrm{Ra}$, Th and $\mathrm{K}$, in $\mathrm{Bq} \mathrm{kg}^{-1}$, respectively. The safety value for this index is $\leq 1$.

\section{RESULT AND DISCUSSION}

\section{Distribution and Interelement Relationship of the Radionuclides}

Many locations were chosen for our study representing 36 stations at El Sela area using Na-I (Tl) include 3 different type of rocks named as follows: two-mica granite, micro- granite and dolerite dike. The results of eU, eTh, eRa, K, eTh/eU, and eU/eRa of the studied samples are listed in (Table. 1) and their radioactivity concentration average were correlated to the corresponding worldwide means (Fig. 11). The microgranite and dolerite dikes show high uranium and radium contents relative to the host rock. Two-mica granite shows a relative lower radioactivity. The concentration of eU at two-mica granite ranges from 5 to $17 \mathrm{ppm}$ with an average of $11.6 \mathrm{ppm}$, the eTh was about 16 to $25 \mathrm{ppm}$ with average of $20.6 \mathrm{ppm}$. The concentration of ${ }^{226} \mathrm{Ra}$ ranges from 7 to $13 \mathrm{ppm}$ with an average of $9.4 \mathrm{ppm}$, while K-40 concentration ranges from 2.32 to $4.11 \%$ with an average of $3.6 \%$ (Fig. 11).

On other hand, the microgranite dike shows high radioactivity. We found that $\mathrm{eU}$ minimum concentration ranges from 14 to 85 ppm with an average of $45 \mathrm{ppm}$ and maximum concentration ranges from 95 to $290 \mathrm{ppm}$ with an average $167 \mathrm{ppm}$. The eTh ranges from 2 to 29 ppm with 9 ppm average. The Ra minimum concentration ranges from 14 to $81 \mathrm{ppm}$ with an average of $45 \mathrm{ppm}$ and maximum concentration range 93 to $222 \mathrm{ppm}$ with an average $160 \mathrm{ppm}$. The k-40 ranges from 1.29 to $3.14 \%$ ppm with an average of $2.2 \%$ (Fig. 11). Dolerite dike shows a relative higher radioactivity. The minimum concentration of eU ranges from 5 to $52 \mathrm{ppm}$ with an average of $38.8 \mathrm{ppm}$

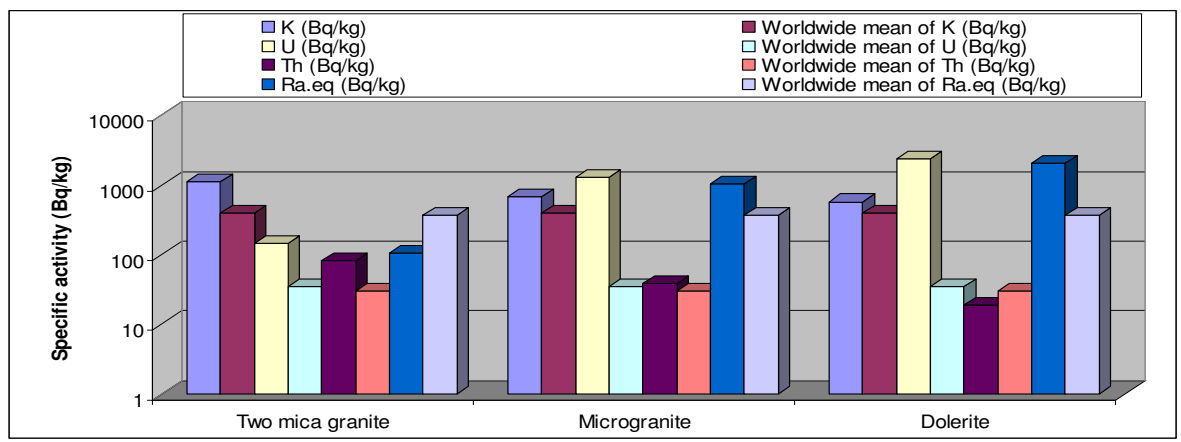

Fig.11: Radionuclides aveage concentration of different rocks at study area with their corresponding worldwide mean 
Table 1: eU, eTh, eRa and $\mathrm{K}$ contents besides eTh/eU and eU/Ra ratios of the studied rocks

\begin{tabular}{|c|c|c|c|c|c|c|c|}
\hline $\begin{array}{l}\text { No of } \\
\text { samples }\end{array}$ & eU(ppm) & eTh(ppm) & eRa(equ) & K \% & eU/eTh & $\mathrm{eTh} / \mathrm{eU}$ & eU/Ra \\
\hline \multicolumn{8}{|c|}{ Two mica granite } \\
\hline Gr1 & 15 & 19 & 9 & 3.49 & 0.79 & 1.27 & 1.67 \\
\hline Gr2 & 8 & 23 & 9 & 4.02 & 0.35 & 2.88 & 0.89 \\
\hline Gr3 & 15 & 16 & 13 & 4.11 & 0.94 & 1.07 & 1.15 \\
\hline Gr4 & 16 & 24 & 11 & 3.70 & 0.67 & 1.50 & 1.45 \\
\hline Gr5 & 8 & 18 & 8 & 2.38 & 0.44 & 2.25 & 1.00 \\
\hline Gr6 & 5 & 16 & 7 & 2.60 & 0.31 & 3.20 & 0.71 \\
\hline Gr7 & 12 & 23 & 8 & 5.80 & 0.52 & 1.92 & 1.50 \\
\hline Gr8 & 15 & 25 & 10 & 4.10 & 0.60 & 1.67 & 1.50 \\
\hline Gr9 & 17 & 24 & 11 & 3.50 & 0.71 & 1.41 & 1.55 \\
\hline Grr10. & 5 & 18 & 8 & 2.32 & 0.28 & 3.60 & 0.63 \\
\hline \multicolumn{8}{|c|}{ Microgranite dike } \\
\hline Mg1 & 121 & 7 & 124 & 3.02 & 17.29 & 0.06 & 0.98 \\
\hline Mg2 & 109 & 2 & 128 & 1.45 & 54.50 & 0.02 & 0.85 \\
\hline Mg3 & 188 & 11 & 141 & 1.58 & 17.09 & 0.06 & 1.33 \\
\hline Mg4 & 37 & 8 & 34 & 2.44 & 4.63 & 0.22 & 1.09 \\
\hline Mg5 & 100 & 10 & 93 & 1.75 & 10.00 & 0.10 & 1.08 \\
\hline Mg6 & 14 & 8 & 14 & 3.14 & 1.75 & 0.57 & 1.00 \\
\hline Mg7 & 50 & 10 & 60 & 1.32 & 5.00 & 0.20 & 0.83 \\
\hline Mg8 & 268 & 29 & 269 & 1.29 & 9.24 & 0.11 & 1.00 \\
\hline Mg9 & 27 & 5 & 24 & 2.22 & 5.40 & 0.19 & 1.13 \\
\hline Mg10 & 95 & 18 & 69 & 1.88 & 5.28 & 0.19 & 1.38 \\
\hline Mg11 & 36 & 4 & 37 & 2.76 & 9.00 & 0.11 & 0.97 \\
\hline Mg12 & 26 & 16 & 18 & 2.83 & 1.63 & 0.62 & 1.44 \\
\hline Mg13 & 75 & 8 & 77 & 1.70 & 9.38 & 0.11 & 0.97 \\
\hline Mg14 & 57 & 4 & 40 & 2.75 & 14.25 & 0.07 & 1.43 \\
\hline Mg15 & 167 & 7 & 141 & 2.84 & 23.86 & 0.04 & 1.18 \\
\hline Mg16 & 290 & 10 & 222 & 1.90 & 29.00 & 0.03 & 1.31 \\
\hline Mg17.... & 85. & 4 & 81. & 2.49 & 21.25 & 0.05 & 1.05 \\
\hline \multicolumn{8}{|c|}{ Dolerite dike } \\
\hline D1 & 727 & 5 & 640 & 1.74 & 145.40 & 0.01 & 1.14 \\
\hline D2 & 52 & 5 & 40 & 1.42 & 10.40 & 0.10 & 1.30 \\
\hline D3 & 36 & 5 & 29 & 1.70 & 7.20 & 0.14 & 1.24 \\
\hline D4 & 5 & 4 & 7 & 2.16 & 1.25 & 0.80 & 0.71 \\
\hline D5 & 173 & 2 & 92 & 3.27 & 86.50 & 0.01 & 1.88 \\
\hline D6 & 160 & $\overline{5}$ & 196 & 1.91 & 32.00 & 0.03 & 0.82 \\
\hline D7 & 492 & 5 & 571 & 0.89 & 98.40 & 0.01 & 0.86 \\
\hline D8 & 49 & 5 & 41 & 1.90 & 9.80 & 0.10 & 1.20 \\
\hline D9 & 52 & 6 & 42 & 1.60 & 8.67 & 0.12 & 1.24 \\
\hline
\end{tabular}

and maximum concentration range from 160 to $727 \mathrm{ppm}$ with an average $388 \mathrm{ppm}$. The eTh ranges from 2 to 6 ppm with 4.76 ppm average. The $\mathrm{Ra}$ minimum concentration range from 7 to $92 \mathrm{ppm}$ with an average of $42 \mathrm{ppm}$ and maximum concentration range from 196 to $640 \mathrm{ppm}$ with an average $469 \mathrm{ppm}$. The k-40 ranges from 0.89 to $3.27 \%$ with an average of $1.84 \%$ (Fig. 11). The high uranium and radium contents are attributed, as mentioned before, to the presence of some pockets and lenses of secondary U-mineralization. All type of rocks has low contents of eTh and K.

The relation between $U$ and Th may indicate the enrichment or depletion of $U$ because Th is generally immobile element. The relation between eU, eTh in studied samples using a number of variation diagrams (Fig. 1215). The microgranite and dolerite dikes show high concentration of eU which indicating $\mathrm{U}$ 
enrichment during magmatic differentiation (Fig. 12).The bivariate diagrams the eU/eTh ratios against $\mathrm{eU}$, eTh contents is shown in (Figs. 13\&14); the ratios show high positive relationships with eU this suggests enrichment of uranium relative to thorium which indicate that the uranium had been added to these dikes by post magmatic uranium mobilization. The $\mathrm{eU} / \mathrm{eRa}$ ratios for most of the mineralized samples from the two localities exceed unity, reflecting a state of radioactive disequilibrium between uranium and its daughter, This state is mostly related to uranium enrichment. The eU-Ra variation diagram indicates that uranium and its daughter are positively correlated, and most samples of the same members have eU/eRa ratios ranging between 1 and 2 (Fig. 15).

\section{Environmental Impact}

\section{Exposure and dose rates}

The international standard unit for dose rate is $1 \mathrm{mSv} / \mathrm{y}$ (Knoll, 2000). The International Commission of Radiological Protection (ICRU 1980) has recommended that no individual should receive more than $50 \mathrm{mSv} / \mathrm{y}$ from all natural and artificial radiation sources in his/her environment (IAEA, 1979). The more recent recommendation of IAEA (1996) suggests a permissible dose rate of $5 \mathrm{mSv} / \mathrm{y}$ for members of the public and $20 \mathrm{mSv} / \mathrm{y}$ for occupational members.

The estimated exposure $(\mathrm{mR} / \mathrm{h})$ and dose rates $(\mathrm{mSv} / \mathrm{y})$ for the studied samples are listed in (Table. 2) (Fig. 16). The average values of the annual dose rate for the studied microgranite and altered basic dike are lower than the permissible values for occupational members and more than the proposed values for publics. This is due to the relative high radiation intensity in the area. Host rock is characterized by low values of the annual dose rates, i.e. less than the permissible values for both occupational and the public members (Fig. 16).

The average values of $\mathrm{Ra}_{\text {eq }}$ in the microgranite and altered basic dike are more than

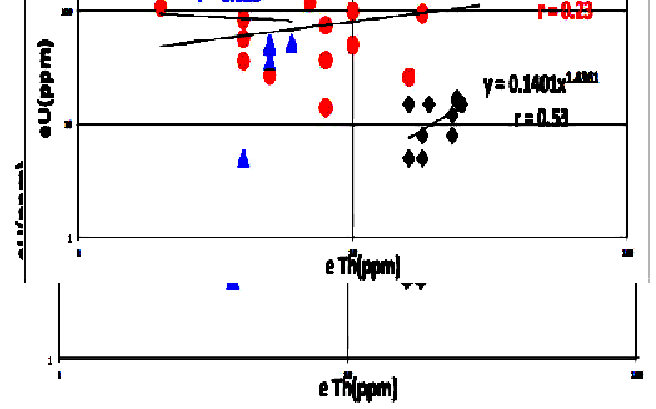

Fig.12: eU vs eTh (Radioelements variation diagrams for studied sample)

( ) Two-mica granite, ( ) Microgranite and ( $)$ dolerite dike

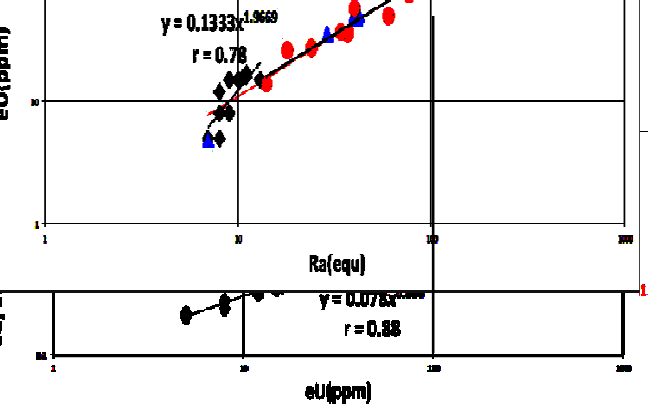

Fig.13: eU vs eU/eTh ratio(Radioelements variation diagrams for studied sample) Symbols as at Fig.12

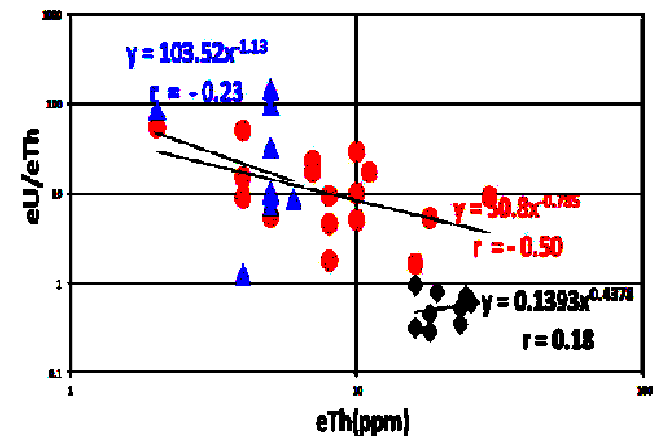

Fig.14: eTh vs eU/eTh ratio (Radioelements variation diagrams for studied sample) Symbols as at Fig. 12 


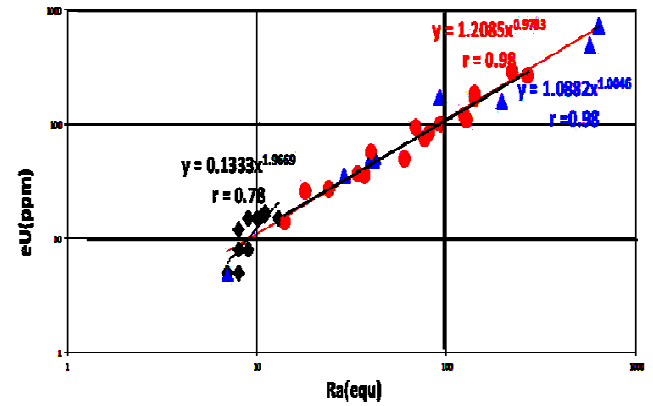

Fig.15: Ra vs eU (Radioelements variation diagrams for studied sample) Symbols as at Fig.12

the permissible values. In the two-micagranite, the average $\mathrm{Ra}_{\mathrm{eq}}$ values are less than the permissible ones

\section{External and internal hazard indices}

The results indicate high values of $\operatorname{Hex}(>1$ $\mathrm{nGy} / \mathrm{y})$ in microgranite and altered basic dike; whereas, the two-micagranite had low values (<1 nGy/y; Table. 2) (Fig. 16).The internal hazard index (Hin) exceeds the permissible value for the microgranite and altered basic dike but not in the two-mica granite. This means that ${ }^{222} \mathrm{Rn}$ and its progeny play a significant role in the expected internal hazard due to radiation from the dikes.

\section{Radioactivity level index (I $\gamma$ )}

The calculated values of I $\gamma$ indicate a very high radioactivity index for microgranite and altered basic dike. The two-mica granite have lower than I $\gamma$ values, but they are still greater than the safety level.

\section{CONCLUSION AND RECOMMENDATIONS}

This study concludes that the rocks at ElSela area are classified, from the radioactivity point of view, into two main groups: host rock and dikes. The dikes have high uranium and radium contents due to the presence of pockets and lenses of secondary U-mineralization. The values of exposure and dose rates, as well as radium equivalent activity, external and internal hazard indices and radioactivity level index of the dikes exceed the permissible values, especially for the public. However, the expected environmental impacts may be low or limited in the study area. This is because of the localized occurrences and areas of U-mineralization, and corresponding limited area for radiation exposure. To avoid any possible environmental impacts from areas and/or raw materials of high intensity of natural radiation sources, the following recommendations and

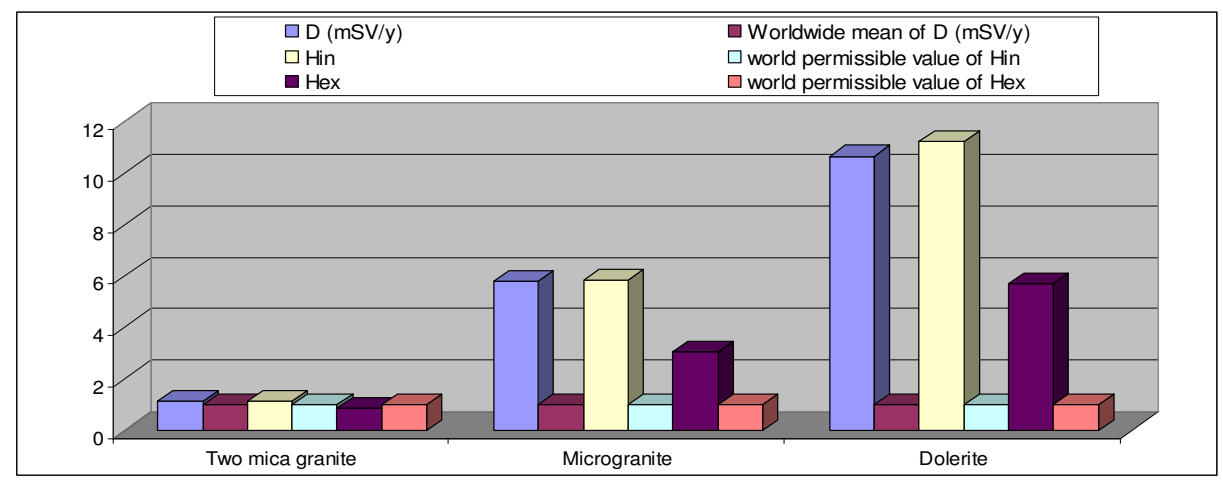

Fig.16: Dose rate (DR), external hazard index (Hex), internal hazard index (Hin) of the studied rocks with their corresponding worldwide mean 
Table 2 : Exposure rate (ER), dose rate (DR), radium equivalent activity $\left(\mathrm{Ra}_{\mathrm{eq}}\right)$, external hazard index (Hex), internal hazard index (Hin) and radioactivity level index (I $\gamma)$ of the studied rocks

\begin{tabular}{|c|c|c|c|c|c|c|c|}
\hline $\begin{array}{l}\text { No of } \\
\text { samples }\end{array}$ & Ra.eq & Hex & Hin & $\mathbf{I} \gamma$ & $\begin{array}{r}\text { Exposure } \\
\text { Dose } \\
\mu \mathrm{R} / \mathrm{h} \\
\end{array}$ & $\begin{array}{r}\text { Dose rate } \\
\mathrm{mrem} / \mathrm{y}\end{array}$ & $\begin{array}{r}\text { Dose } \\
\text { rate } \\
\mathrm{mSV} / \mathrm{y} \\
\end{array}$ \\
\hline \multicolumn{8}{|c|}{ Two-mica granite } \\
\hline Gr1 & 285.37 & 0.79 & 1.06 & 2.16 & 15.31 & 127.54 & 1.28 \\
\hline Gr2 & 319.92 & 0.89 & 1.16 & 2.43 & 11.90 & 99.10 & 0.99 \\
\hline Gr3 & 326.14 & 0.91 & 1.30 & 2.47 & 14.46 & 120.46 & 1.20 \\
\hline Gr4 & 340.85 & 0.95 & 1.28 & 2.56 & 17.40 & 144.96 & 1.45 \\
\hline Gr5 & 244.21 & 0.68 & 0.92 & 1.82 & 10.43 & 86.90 & 0.87 \\
\hline Gr6 & 226.45 & 0.63 & 0.84 & 1.71 & 7.90 & 65.84 & 0.66 \\
\hline Gr7 & 347.82 & 0.98 & 1.22 & 2.73 & 14.54 & 121.13 & 1.21 \\
\hline Gr8 & 344.25 & 0.96 & 1.26 & 2.61 & 17.04 & 141.97 & 1.42 \\
\hline Gr9 & 336.47 & 0.93 & 1.26 & 2.51 & 18.05 & 150.37 & 1.50 \\
\hline Gr10 & 242.89 & 0.67 & 0.91 & 1.80 & 8.47 & 70.58 & 0.71 \\
\hline \multicolumn{8}{|c|}{ Microgranite dike } \\
\hline Mg1 & 1482.73 & 4.03 & 7.75 & 10.09 & 81.08 & 675.36 & 6.75 \\
\hline Mg2 & 1464.04 & 3.97 & 7.81 & 9.86 & 71.78 & 597.90 & 5.98 \\
\hline Mg3 & 1662.82 & 4.50 & 8.73 & 11.21 & 125.95 & 1049.16 & 10.49 \\
\hline Mg4 & 476.75 & 1.30 & 2.32 & 3.35 & 26.50 & 220.75 & 2.21 \\
\hline Mg5 & 1128.01 & 3.06 & 5.85 & 7.65 & 68.20 & 568.12 & 5.68 \\
\hline Mg6 & 270.09 & 0.75 & 1.17 & 2.01 & 11.49 & 95.75 & 0.96 \\
\hline Mg7 & 752.29 & 2.04 & 3.84 & 5.12 & 35.54 & 296.08 & 2.96 \\
\hline Mg8 & 3180.53 & 8.61 & 16.68 & 21.35 & 183.35 & 1527.31 & 15.27 \\
\hline Mg9 & 343.72 & 0.94 & 1.66 & 2.44 & 19.11 & 159.15 & 1.59 \\
\hline Mg10 & 910.35 & 2.47 & 4.54 & 6.23 & 67.23 & 560.06 & 5.60 \\
\hline Mg11 & 494.12 & 1.35 & 2.46 & 3.48 & 24.71 & 205.80 & 2.06 \\
\hline Mg12 & 353.59 & 0.97 & 1.51 & 2.57 & 21.62 & 180.10 & 1.80 \\
\hline Mg13 & 937.84 & 2.55 & 4.86 & 6.38 & 51.30 & 427.34 & 4.27 \\
\hline Mg14 & 527.20 & 1.44 & 2.64 & 3.70 & 38.42 & 320.02 & 3.20 \\
\hline Mg15 & 1667.48 & 4.52 & 8.75 & 11.31 & 111.11 & 925.55 & 9.26 \\
\hline Mg16 & 2563.20 & 6.94 & 13.60 & 17.23 & 192.27 & 1601.64 & 16.02 \\
\hline Mg17 & 976.60 & 2.65 & 5.08 & 6.68 & 56.70 & 472.29 & 4.72 \\
\hline \multicolumn{8}{|c|}{ Dolerite dike } \\
\hline D1 & 7170.81 & 19.39 & 38.59 & 47.93 & 476.20 & 3966.72 & 39.67 \\
\hline D2 & $\mathbf{5 0 3 . 8 0}$ & 1.37 & 2.57 & 3.46 & 35.42 & 295.02 & 2.95 \\
\hline D3 & 387.83 & 1.06 & 1.93 & 2.70 & 24.97 & 208.03 & 2.08 \\
\hline D4 & 147.97 & 0.41 & 0.62 & 1.13 & 4.45 & 37.08 & 0.37 \\
\hline D5 & 1104.32 & 3.00 & 5.76 & 7.57 & 113.60 & 946.30 & 9.46 \\
\hline D6 & 2246.13 & 6.08 & 11.96 & 15.10 & 105.95 & 882.56 & 8.83 \\
\hline D7 & 6386.28 & 17.27 & 34.40 & 42.64 & 322.73 & 2688.32 & 26.88 \\
\hline D8 & 525.41 & 1.43 & 2.66 & 3.63 & 33.47 & 278.77 & 2.79 \\
\hline D9 & 535.68 & 1.46 & 2.72 & 3.68 & 35.71 & 297.44 & 2.97 \\
\hline
\end{tabular}


precautions are suggested, to be considered during any future exploration processes with materials of relatively high radioactive intensity:

1. The direct contact and handling of the highly radioactive samples and/or ores (if present) as well as their products should be minimized or eliminated to reduce the time of radiation exposure.

2. Use personal protective masks to minimize inhalation of $\alpha$-particles.

3. Provide medical surveillance for the workers.

4. Provide the use of portable dosimeters and their periodical inspection.

5. Apply shift work when exposed to the hazardous mineralized sediments.

\section{REFERENCES}

Abdel Gawad, A.E.; Orabi, A.H., and Bayoumi, M.B., 2014. Uranium Evaluation and Its Recovery from Microgranite Dike at Gabal El Sela area, South Eastern Desert, Egypt. In Press.

Abdel Meguid, A. A.; Cuney, M.; Ammar, S. E.; Ibrahim, T. M. M.; Ali, K. G.; Shahin, H. A.; Omer, S. A.; Gaafar, I. M.; Masoud, S. M.; Khamis, A. A.; Haridy, H. M.; Kamel, A. I.; Mostafa, M. B.; Abu Donia,. A. M.; Abdel Gawad, A. E., and Aly, E. M., 2003. Uranium Potential of Eastern Desert Granites, Egypt. Internal report, NMA, Cairo, Egypt.

Abo Donia, A.M., 2006. Some applications of geological and geophysical techniques in uranium explorations and defining favorable structures in El-Sela Area, South Eastern Desert, Egypt. M.Sc. Thesis, Moniufiya Univ., Egypt,164 p.

Ali, K.G., 2011. Structural Control of El Sela Granites and Associated Uranium Deposits, South Eastern Desert, Egypt.

Al-Jundi, J., 2002. Population doses from terrestrial gamma exposure in areas near to old phosphate mine, Russaifa, Jordan. Radiat. Arabian J. Geo- sciences, Meas. 35, 23e28.

Beretka, J., and Mathew, P.J., 1985. Natural radioactivity of Australian building materials, industrial wastes and by-products. Health Phys. 48, $87 \mathrm{e} 95$.

Cuney, M.; Le fort, P., and Wang, Z.X., 1984. Uranium and Thorium Geochemistry and Mineralogy in the Manasluleucogranite (Nepal, Himalaya): Geology of Granites and Their Metallogenetic Relations (Proc. Symposium), Nanjing, 1982, Univ. Sciences Editions, 853-873.

El-Afandy A.H.; Ibrahim T.M.; Ali K.G.; Gaafar I.M.;Masoud S.M.; Omer S.A.; Shahin H.A.; Farag S.S.; Abu Donia A.M.; Aly E.M.; Omran A.A.; Abdel Gawad A.E.; Bayoumi M.B.; El Werdani M.H.; Abdalla O.Kh.; Abdel Fataah M.F.; Esmat R.A., and Zaher F.Y., 2008. Uranium Resource Development: El Sela development project, South Eastern Desert, Egypt, Internal Report.

Friedrich, M.H.; Cuney, M., and Cregu, G., 1989. Uranium Enrichment Processes in Peraluminous Magmatism. International Atomic Energy Agency (IAEA)-TC-571/2.11-35.

Gaafar, I.M., 2005. Applications of Geological and Geophysical Survey for Defining the Uranium Potentiality of Some Younger Granites in the Eastern Desert of Egypt. Unpublished Ph.D., Fac. Sci., Mansoura Univ., Mansoura, 186 p.

Hamby, D.M., and Tynybekov, A.K., 2000. Uranium, thorium and potassium in soils along the shore of lake IssyK-Kyol in the Kyrghyz Republic. Environ.Monit. Assess. 73, 101e108.

Helgeston H.C., 1974. Chemical interaction of feldspars and aqueous solution in the feldspars, W. L. Mackenzie and J. Zussman: eds. Manchester Univ. press, 184-215

Ibrahim, M.E.; Abd-El-Wahed, A.A.; Oraby, Abu El-Hassan, ElGaly, M.M., and Watanabbe, K., 2007. Studied the factors controlling mineralization I a lamprophyre dyke, Abu Rusheid area, Eastern Desert, Egypt.1, P 79-92 (OCT.2007) Assiut-Egypt. 
International Atomic Energy Agency, (IAEA), 1996. Internal Basic Safety Standards for Protection against Ionizing Radiation and for the Safety ofRadiation Sources. Safety Series No. 115.

International Atomic Energy Agency, (IAEA), 1979. Gamma-ray Surveys in uranium Exploration. Technical Reports Series No. 186, Vienna, $89 \mathrm{p}$.

International Commission on Radiation Units and Measurements, (ICRU), 1980. Radiation Quantities and Units. Report 33, Washington, DC.J. Environ. Radioact. 73, 233245.

Knoll, G.F., 2000. Radiation Detection and Measurement, $3^{\text {th }}$ ed. Univ. Michigan, Wiley, New York.

Malczewski, D.; Taper, L., and Dorda, J., 2004. Assessment of natural and anthropogenic radioactivity levels in rocks and soils in the environs of Swieradow Zdroj in Sudetes, Poland by in situ gamma-ray spectrometry.J. Environ. Radioact. $73,233 \mathrm{e} 245$.

Matolin, M., 1991. Construction and Use of Spectrometric Calibration Pads Laboratory-ray Spectrometry, NMA, Egypt. A Report to the Government of the Arab Republic of Egypt. Project EGY/4/030-03. IAEA.

Nada, A., 2003. Evaluation of natural radionuclides at Um-Greifat area, eastern desert of Egypt. Appl Radiat Isot, 58,275-280.

Nuclear Energy Agency, NEA-OECD., 1979. Exposure to Radiation from Natural Radioactivity in Building Materials. Report by NEA Group of Experts. OECD, Paris.

Pal, D.C.; Mishra, B., and Bernhardt, H.J., 2007.
Mineralogy and Geochemistry of PegmatiteHosted Sn-, Ta-Nb- and Zr-Hf-Bearing Minerals from the Southereastern Part of the BastarMalkangiri Pegmatite Belt, Central India. Ore Geology Reviews, 30, 30-55. http://dx.doi. org/10.1016/j.oregeorev.2005.10.004

Poty, B.; Cuney, M., and Friedrich, M., 1986. Uranium Deposits Spatially Related to Granites in the French Part of the Hercynian Orogeny, Vein Type Uranium Deposits. IAEA-TECDOC-361, IAEA, Vienna, 215-246.

Rameshbabu, P.V., 1999. Rare Metal and Rare Earth Pegmatites of Central India. Special Issue on Rare Metal and Rare Rarth Pegmatites of India. Exploration and Resarch,12, 7-52.

Rumyantsev, S., 1967. Industrial Radiology. Translated from the Russian by Semyonov, S. Mir Publishers, Moscow.

Saito, K., and Jacob P., 1995. Gamma-ray fields in air due to sources in the ground. Radiat Prot Dosim. 58,29-45:29.

Saito, K.; Pattoussi, H., and Zank1, M., 1998. Calculation of the effective dose and its variation from environmental gamma ray sources. Health Phys ,74, 698-706

Tufail, M.; Ahmed, M.; Shaib, S.; Safdar, A.; Mirza, N.M.; Ahmed, N.; Zafar, M.S.,and Zafar, F.I., 1992. Investigation of gamma-ray activity and radiological hazards of the bricks fabricated around Lahor, Pakistan. Pak. J. Sci. Ind. Res. 34, $216 \mathrm{e} 220$.

United Nations Scientific Committe on Effects of Ionizing Radiations ,UNSCEAR., 2000. Sources and Effects of Ionizing Radiation. UNSCEAR Report on the General Assembly with Scientific Annexes, 1, Sources. 


\section{توزيع العناصر المشعة في صخور الجرانيت ثنائي الميكا المشع والتقيم البيئي في

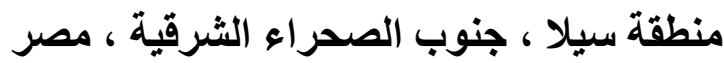

$$
\text { عادل حسن الافندى، احمد عبد العزيز الكمار ، احمد السيد عبد الجوادو طاهرنصررزق }
$$

تتناول هذه الدر اسةتوزيع النشاط الأشعاعي الطبيعي لصخور الجر انيت ثنائي الميكا المشع و التأثيرات البيئية المرتبطة بها في منطقة السيلا ، حيث تم حساب معدل التعرض ومعدل الجر عه الأشعاعية ونشاط

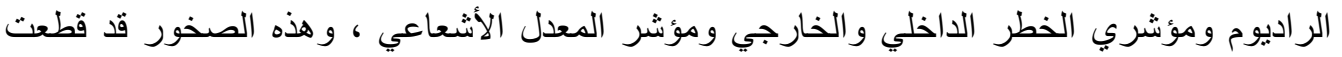

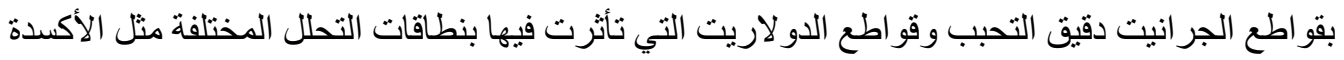

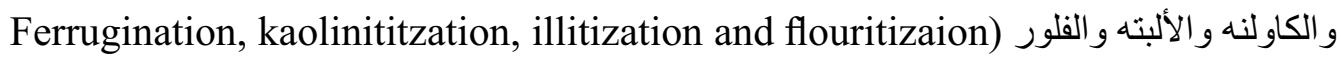

$$
\text { ) الحاملة لمعادن اليور انيوم الثانوية . ولئه }
$$

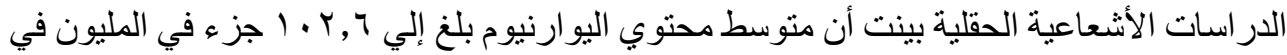
قو اطع الجر انيت دقيق التحبب وكذلك ـ9 19 جزء في المليون في قواطع الدو لايت علي التوالي ، وكذللك

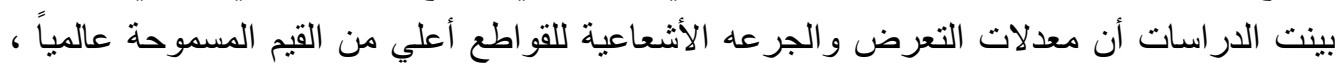
وكانت معدلات التعرض الجرعه ضمن نطاق السلامة للعاملين والجمهور في الجرانيت ثنائي الميكا 